\title{
Establishment of Chinook salmon (Oncorhynchus tshawytscha) in Pacific basins of southern South America and its potential ecosystem implications
}

\author{
Establecimiento del salmón Chinook (Oncorhynchus tshawytscha) en cuencas del Pacífico \\ sur de Sudamérica y sus potenciales implicancias ecosistémicas
}

DORIS SOTO ${ }^{1,2}$, IVÁN ARISMENDI ${ }^{1}$, CECILIA DI PRINZIO $^{3}$ \& FERNANDO JARA ${ }^{4}$

${ }^{1}$ Laboratorio de Ecología Acuática, Instituto de Acuicultura, Universidad Austral de Chile, Campus Puerto Montt y Núcleo Milenio FORECOS

${ }^{2}$ Present address: Inland Water Resources and Aquaculture Service (FIRI), Fisheries Department, FAO of

United Nations, Via delle Terme di Caracalla, 00100, Rome, Italy

${ }^{3}$ Laboratorio de Investigaciones en Ecología y Sistemática Animal (UNPAT)-CONICET Esquel (Chubut), Argentina

${ }^{4}$ Universidad San Sebastián, Puerto Montt, Chile

\begin{abstract}
Salmon and trout species are not native to the southern hemisphere, however rainbow and brown trout have been established a century in southern South America. Yet most attempts to introduce anadromous salmon failed until the onset of aquaculture by 1980 . Escapes of Oncorhynchus tshawytscha (Chinook salmon) from aquaculture after 1990 have apparently produced increasingly important reproductive returns "naturalized", to upper basins in Chile and Argentina south of $39^{\circ} \mathrm{S}$. In this paper we show data on the historic and spatial occurrence of chinook salmon in four Pacific basins during the past decade. Our objective is to establish the progress of the settlement forecasting some ecosystem disruptions in order to project and manage potential impacts. In Chile, sampling took place from 1995 to 2005 including rivers Petrohué, Poicas, and Río NegroHornopiren, and Lake Puyehue, in the X Region. In Argentina sampled rivers were Futaleufú, Carrenleufú and Pico. In Chile and Argentina reproductive Chinooks ranged in size between 73 and $130 \mathrm{~cm}$ total length, being the smallest sizes those of Lake Puyehue where the population is apparently landlocked. In Río Petrohué, the size of the runs varied from year to year reaching in the peak season of 1996 and 2004 up to $500 \mathrm{~kg}$ of fish along $100 \mathrm{~m}$ of riverbank. Temporal distribution of juvenile Chinooks suggested mainly a typical ocean type as they are gone to sea within the first year of age. As seen in Petrohue, reproductive populations could import significant quantities of marine derived nutrients as they do in their original habitats thus disturbing natural cycles and balances. Chinook establishment in these pristine watersheds in southern South America poses new challenges for decision makers and fishermen since they may develop a fishery in the Pacific Ocean with consequences to other fishery resources. Additionally they also become a resource for sport fishing. Therefore there is the need of developing management tools and approaches to control the populations avoiding irreversible ecosystem disruptions and social conflicts.
\end{abstract}

Key words: salmon invasion, naturalized populations, nutrients uploads, sport fishing potential.

\section{RESUMEN}

Los salmonídeos no son nativos del hemisferio sur, y es así que las truchas (arcoiris y café) se establecieron en el sur de Sudamérica hace un siglo. La mayoría de los intentos por introducir salmones anádromos falló hasta el establecimiento de la acuicultura en los años ochenta. A partir de 1990, aparentemente debido a escapes de Oncorhynchus tshawytscha (salmón Chinook) de cultivo, se están produciendo retornos reproductivos de esta especie en cuencas chilenas y argentinas al sur de los $39^{\circ} \mathrm{S}$. En este trabajo se muestra la ocurrencia histórica y espacial de salmón chinook en cuatro cuencas de vertiente Pacífica durante la última década. Nuestro objetivo es establecer el progreso de su establecimiento al tiempo que se proyectan algunos impactos así como alternativas de manejo. En Chile, el muestreo se realizó entre 1995 y 2005 incluyendo los ríos Petrohué, Poicas, Río Negro-Hornopirén, y el Lago Puyehue, en la X Región. En Argentina los ríos muestreados incluyen al Futaleufú, Carrenleufú y Pico. En las cuencas chilenas y argentinas los Chinook reproductivos alcanzaban 73 a $130 \mathrm{~cm}$ de largo total encontrándose los más pequeños en el Lago Puyehue donde la población estaría encerrada. En el Río Petrohué, los retornos variaron de año en año alcanzando máximos en 1996 y en el 2004 de hasta $500 \mathrm{~kg}$ de pescado en una extensión de 100 m de río. La distribución 
temporal de juveniles sugiere que principalmente se trata del tipo chinook oceánico ya que migrarían al mar durante el primer año de vida. Como se observa en Petrohué, poblaciones reproductivas de la especie aportarían cantidades relevantes de nutrientes de origen marino tal como ocurre en sus hábitats naturales, produciendo así una importante perturbación a los balances y ciclos naturales en estos sitios. El establecimiento de poblaciones de Chinook en el sur de Sudamérica, genera nuevos desafíos a pescadores y autoridades ya que se podría desarrollar una pesquería de la especie en el océano Pacífico con consecuencias sobre otros recursos pesqueros. Adicionalmente también se transforman en un recuso para la pesca deportiva. Por ello se hace necesario desarrollar herramientas de manejo y control sobre la población para evitar perturbaciones ecológicas y ecosistémicas irreversibles.

Palabras clave: invasión de salmonídeos, poblaciones naturalizadas, ingreso de nutrientes, potencial de pesca deportiva.

\section{INTRODUCTION}

The Pacific salmon (Oncorhynchus spp.) from North America has been introduced to several areas in the world because of its high nutritional value and as a prized sport fishing catch. Introduction purposes have aimed at ranching, sport and commercial fisheries, and aquaculture (Soto et al. 2001b, Basulto 2003).

In the Patagonian waterways of Argentina and Chile, native fish fauna is poor in diversity (Ringuelet et al. 1967, Campos 1974, Campos et al. 1998), and with almost no sports fishery value due to the small body size of the fish and/or to the fact that they are not as attractive as the more popular introduced trout. Around 1900, with sport fishing as a target, the first salmon eggs were brought to Chile (Basulto 2003) and to Argentina from the Northern Hemisphere. In 1924, eggs of Chinook salmon (Oncorhynchus tshawytscha) were imported from the United States and were sown in the river basins of Maullín, Cochamó and Puelo in the Los Lagos region (Fig. 1). In 1930, eggs of sockeye (O. nerka) and coho (O. kisutch) were also introduced from the United States. However, of all the salmonid species introduced to Argentina (10 species) and Chile (11 species) only a few have established self-sustaining populations (Mendez \& Munita 1989, Pascual et al. 2002). Rainbow trout (O. mykiss), brown trout (Salmo trutta) and brook trout (Salvelinus fontinalis) became established in almost all Patagonian basins in Argentina, whereas only the first two have been truly successful in Chile (Soto et al. 2006).

Chile has pioneered the development of salmon aquaculture in America; the great majority of it taking place in the $10^{\text {th }}$ and $11^{\text {th }}$ administrative geographic regions (Soto et al. 2001b, Basulto 2003). The initiative, started by Domsea Farms in the 1970's, set a landmark in Chilean aquaculture by developing coho (O. kisutch) and Chinook salmon (O. tshawytscha) "ocean ranching". The first returns of this "ranching" were obtained in 1979; returns continued intermittently until 1991 when they disappeared (Mendez \& Munita 1989). More recently, and due to Chilean salmon farming, escapees of Chinook have run into Patagonian rivers of Pacific outlet in Chile and Argentina, spawning in many of these areas (Soto et al. 2001b). In their natural habitats in the northern hemisphere, chinook return to their natal rivers after spending about 3 to 8 years in the ocean; the return to fresh water marks the end of their life cycle as semelparous fish that reproduce once and then die (Healey 1991).

In most lakes, fjords, and channels with salmon farming in southern Chile $\left(39-44^{\circ} \mathrm{S}\right)$ there have been escapees, which include rainbow trout, coho, Chinook, and Atlantic salmon. However, massive returns have been reported only for Chinook. Indeed, massive reproductive runs were recorded from Petrohué (41 ${ }^{\circ} 12^{\prime} \mathrm{S}$ ) in Chile starting 1995 (Soto et al. 2001b). Previously, Grossman (1991, 1992) had reported the presence of chinook in the Río Futaleufú in Argentina. From available records we can infer regular returns during the Austral summer and fall in at least three Pacific slope basins of the Chubut province in Argentina (Futaleufú, Corcovado, and Pico), and in the Petrohué and Negro basins in Chile (Fig. 1).

Of all the Pacific salmon species, Chinook is the one attaining the largest sizes and the one that performs the longest migrations (Healey 1991). In addition, it requires large alluvial rivers for its reproduction (Geist \& Dauble 1998). 


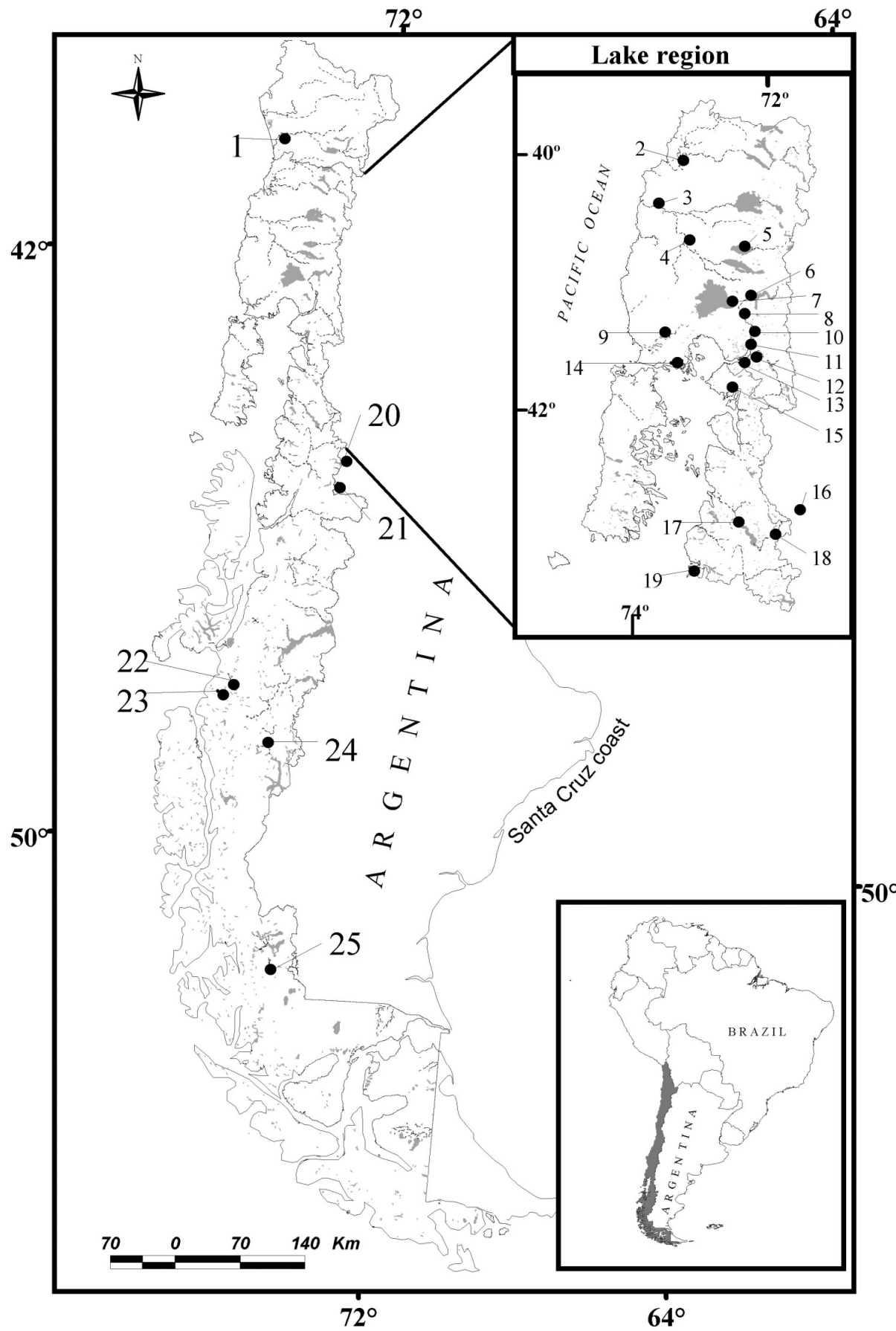

Fig. 1: Study sites: 1 = Río Toltén, 2 = Río Valdivia, 3 = Río Bueno, 4 = Río Pilmaiquén, 5 = Lago Puyehue, 6 = Lago Todos los Santos, 7 = Laguna Los Patos, 8 = Río Petrohué, 9 = Río Maullín, 10 = Cochamó, 11 = Estuario del Reloncaví, 12 = Río Poicas, 13 = Río Puelo, 14 = Calbuco, $15=$ Río Negro, 16 = Río Futaleufú en Argentina, 17 = Lago Yelcho, 18 = Río Futaleufú, 19 = Río Palena, 20 = Río Carrenleufu, 21 = Río Pico, 22 = Río Vargas, 23 = Río Jaramillo, 24 = Río Pascua, $25=$ Puerto Natales.

Sitios de estudio: 1 = Río Toltén, 2 = Río Valdivia, 3 = Río Bueno, 4 = Río Pilmaiquén, 5 = Lago Puyehue, 6 = Lago Todos los Santos, 7 = Laguna Los Patos, 8 = Río Petrohué, 9 = Río Maullín, 10 = Cochamó, 11 = Estuario del Reloncaví, $12=$ Río Poicas, 13 = Río Puelo, 14 = Calbuco, 15 = Río Negro, 16 = Río Futaleufú en Argentina, $17=$ Lago Yelcho, $18=$ Río Futaleufú, 19 = Río Palena, 20 = Río Carrenleufu, 21 = Río Pico, 22 = Río Vargas, 23 = Río Jaramillo, 24 = Río Pascua, 25 $=$ Puerto Natales. 
Many attempts have bee made worldwide to establish populations of anadromous species, but few have been successful (Mendez \& Munita 1989). One such case was the introduction of Chinook salmon in New Zealand at the beginning of the $20^{\text {th }}$ century (Waugh 1980, McDowall 1990). A more recent "potential" settlement of Chinook in southern South America is the one referred to in this study. Factors that may determine successful settlements are of interest particularly when, in its native habitat, the species is deemed "endangered" and cited under the Endangered Species Act (ESA) of North America (Lichatowich 1999, Willson 2003).

Impacts of introduced anadromous species on native populations could result from direct, indirect, or cascade effects both in the ocean and in freshwater habitats. A significant such impact may result from the transport of nutrients to the river basins from the ocean (Kline et al. 1993, Naiman et al. 2002) when salmon return and later die and decompose or are eaten in reproductive areas. This issue merits attention in the case of southern Chile, since Chinook are invading mostly pristine areas that nutrient-wise may resemble preindustrial northern hemisphere salmon country.

Another issue we raise in this paper deals with the difficult dilemma about conservation of native biodiversity and foreign species introductions, especially when the alien species is considered valuable from a commercial and recreational perspective.

In this paper we show data on the historic and spatial occurrence of $O$. tshawytscha (chinook salmon) in four Pacific basins (three of them trans-Andean) during the past decade. Our objective is to establish the spatial and numeric progress of Chinook settlement in southern South America forecasting some ecosystem disruptions in order to project and manage potential impacts.

\section{MATERIAL AND METHODS}

\section{Study area}

In Chile, main hydrographic watersheds are born from the Andes mountains and flow towards the Pacific Ocean, in an east to west direction. South to $40^{\circ} \mathrm{S}$ there are trans-Andean basins (Niemeyer \& Cereceda 1984) that also flow in an east-west direction from Argentina to Chile (Fig. 1); these are also known as "Pacific slope Argentinean basins". Most of the basins studied here originate in Andean or preAndean lakes.

Watersheds from the $10^{\text {th }}$ Region, in Chile, were extensively sampled including all the great lakes (Soto et al. 2006). However, the present study includes only those basins where Chinook specimens were found. This was also the case with the Chubut Province in Argentina. Table 1 presents data including river discharge and length of main rivers, of all the watersheds sampled. Sites included correspond to the Argentinean basins of Pacific slope Futaleufú, and the sub-basins Carrenleufú and Pico (Fig. 1), and the Pacific basins of the rivers Petrohué and Hornopirén. Information is also included for Lago Puyehue in Chile (Fig. 1) as part of the Río Bueno basin where there would be a partially "landlocked" Chinook population.

\section{Sampling of Chilean rivers and lakes}

Sampled rivers included in the study are, Petrohué, Poicas, and Rio Negro-Hornopiren, additionally, as mentioned above, we include information on Lake Puyehue within Rio Bueno watershed (Table 1). The most intensely evaluated river has been Río Petrohué, an effluent from Lago Todos Los Santos and tributary to the Reloncaví estuary (Fig. 1), because the most conspicuous runs were initially observed here. The main reproductive activity is found in a river branch of approximately $1,200 \mathrm{~m}$ long by $30 \mathrm{~m}$ wide and an average depth of $1.1 \mathrm{~m}$ (range 0.6-1.8 m), with lower water velocity (70 to $110 \mathrm{~cm} \mathrm{seg}^{-1}$ ), and lower water depth $(55$ to $120 \mathrm{~cm})$ than the main course of the Río Petrohué (Table 1). This site named "Los Patos lagoon" is located approximately $500 \mathrm{~m}$ down the Petrohué Falls (of approximately $20 \mathrm{~m}$ high). The substratum at the spawning area corresponds to clastic rocks or volcanic ashes of spherical to semispherical type, dark in color, which cover the whole range from sands and gravel up to boulders. Measured redd material resulting in highly spherical gravel of $0.6 \mathrm{~cm}$ average diameter (size range 0.6-7.7 cm). The canal bed is covered by clumps of fine foliage aquatic 
plants (Myriophyllum sp.). Most of this watercourse runs within the Vicente Perez Rosales National Park, on its banks vegetation is abundant and essentially pristine. Between 2002 and 2005, water temperature at "Los Patos site varied between 8 and $15{ }^{\circ} \mathrm{C}$ being the lowest during August, coinciding with Lago Todos Los Santos thermal regime (Campos et al. 1990).

Sampling at Los Patos started in April 1995 when direct visual estimates of fish density were made of returning specimens (including the recently dead) along a $150 \mathrm{~m}$ stretch. Starting in the fall of 1996 (April) and thereafter every fall until 2005, and whenever possible, we used monofilament nets, diving, and underwater video recording which allowed counting/ measuring individuals and redds. When river conditions did not allow evaluation of alive individuals we made estimates of the size distribution based upon spawned-out fishes. Total egg counts were completed for captured mature females recently arriving to the spawning grounds.
To estimate potential nutrient contributions in the form of dissolved nutrients $\left(\mathrm{PO}_{4}\right.$ and DIN $=\mathrm{NO}_{2}+\mathrm{NO}_{3}+\mathrm{NH}_{4}$ ) due to decomposing spawned-out Chinook salmon, duplicate water samples were taken before and on the spawning site (temporal comparisons) on each sampling visit between 2003 and 2005. Additionally, on three occasions (April, September 2003 and April 2005) samples were also taken of the same river in a nearby area (spatial comparisons), above the spawning site close to the riverhead water at lake Todos los Santos. This area should be unaffected by spawning due to a high water fall in between ("Saltos del Petrohué") and indeed no spawners have been observed there. In addition, we compared dissolved nutrient data from similar rivers in the region, obtained from the literature and from our own team (Soto et al. 2006). All nutrient analyses have been carried out following methods described by Wetzel \& Likens (2000) except for $\mathrm{NO}_{3}-\mathrm{N}$, which was analyzed spectrophotometrically after sodium salicylate treatment (Soto 2002).

TABLE 1

Information and capture techniques of main watersheds where Chinook salmon populations have been evaluated within this study or have been reported by fisherman

Información y técnicas de captura en las principales cuencas donde se han evaluado poblaciones de salmón Chinook en el marco de este estudio o donde han sido reportadas por los pescadores

\begin{tabular}{|c|c|c|c|c|c|c|c|}
\hline Watershed & Latitude & Origin & $\begin{array}{c}\text { Area of } \\
\text { basin }\left(\mathrm{km}^{2}\right)\end{array}$ & $\begin{array}{c}\text { Length } \\
\text { of river** }(\mathrm{km})\end{array}$ & $\begin{array}{l}\text { Altitude } \\
(\mathrm{m})\end{array}$ & $\begin{array}{c}\text { Average Q } \\
\left(\mathrm{m}^{3} \mathrm{~s}^{-1}\right)\end{array}$ & $\begin{array}{l}\text { Evaluation } \\
\text { method* }\end{array}$ \\
\hline Toltén & $39^{\circ} 05^{\prime} \mathrm{S}$ & Chile & 8,040 & 23 & 134 & 323 & FMR \\
\hline Valdivia & $40^{\circ} 10^{\prime} \mathrm{S}$ & Chile / Argentina & 11,320 & 55 & 50 & 600 & FMR \\
\hline $\begin{array}{l}\text { Pilmaiquen } \\
\text { (Lago Puyehue) })^{\#}\end{array}$ & $40^{\circ} 37^{\prime} \mathrm{S}$ & Chile & 2,680 & 68 & 184 & 176 & GN \\
\hline Bueno & $40^{\circ} 10^{\prime} \mathrm{S}$ & Chile & 17,210 & 130 & 50 & 372 & FMR \\
\hline Maullín & $40^{\circ} 33^{\prime} \mathrm{S}$ & Chile & 4,298 & 85 & 50 & 100 & GN \\
\hline Petrohué & $41^{\circ} 12^{\prime} \mathrm{S}$ & Chile & 2,644 & 36 & 189 & 278 & $\mathrm{EF}$ \\
\hline Poicas & $41^{\circ} 33^{\prime} \mathrm{S}$ & Chile & 24 & 10 & 30 & 5 & $\mathrm{EF}$ \\
\hline Negro Hornopirén & $41^{\circ} 57^{\prime} \mathrm{S}$ & Chile & 200 & 23 & 50 & 60 & $\mathrm{GN}-\mathrm{EF}$ \\
\hline Futaleufú & $42^{\circ} 15^{\prime} \mathrm{S}$ & Chile/Argentina & 11,600 & 246 & 6 & 363 & SF - GN \\
\hline \multicolumn{8}{|l|}{ Carrenlelfu/ } \\
\hline Corcovado & $43^{\circ} 54^{\prime} \mathrm{S}$ & Chile / Argentina & 880 & 60 & 850 & 47 & SF \\
\hline Pico-Palena & $44^{\circ} 20^{\prime} \mathrm{S}$ & Chile / Argentina & 12,887 & 240 & 500 & 700 & SF - GN \\
\hline
\end{tabular}

* Electrofishing (EF), gillnet (GN), sport fishing (SF), fisherman reports (FMR)

** Approximate distance to the ocean except for Carrenlelfu which drains to Palena (inner seas of Chiloe, Fig. 1); \# data on Lake Puyehue from Soto et al. (2001a) 
The presence of juveniles and the potential impact of the spawning Chinook on other fish species at Los Patos site was evaluated using electro fishing gear (Smith and Root Model 12B Power electro fisher); four to six sampling events were carried out every year between July 1999 and January 2005. Electro fishing was carried out repeatedly covering each time a stretch of the river approximately $300 \mathrm{~m}$ long by $3 \mathrm{~m}$ wide for 30 minutes or more, until the catch of $90 \%$ or more of the fish in the area was secured. All fish specimens caught were identified and counted, thus obtaining abundance (fishes $\mathrm{m}^{-2}$ ) according to the methodology described in Soto et al. (2006). All fishes were measured, weighed, and then released.

The two lesser rivers where juvenile Chinooks have been recorded are the Río Poicas tributary to the large Río Puelo which flows into the Reloncaví Estuary, and a tributary to the Río Negro Hornopirén which runs into the inner sea in continental Chiloé (Fig. 1). These are shorter rivers closer to the sea, both drain first to second order mountain streams, and have very transparent waters with an estimated average discharge of 1.6 and $6 \mathrm{~m}^{3}$ $\mathrm{sec}^{-1}$, respectively. Their beds have pebbly bottoms where rocks 10 to $20 \mathrm{~cm}$ in diameter prevail with average depths of $50-70 \mathrm{~cm}$. In both cases, the riparian vegetation is abundant, with scarce human intervention. During the sampling period temperatures varied from 4.5 ${ }^{\circ} \mathrm{C}$ in July to $15.2{ }^{\circ} \mathrm{C}$ in January at Río Poicas, while at Río Negro the variation was from $6{ }^{\circ} \mathrm{C}$ in July to $9{ }^{\circ} \mathrm{C}$ in February. Similar sampling methodology to that described for Petrohué was applied in the later two rivers between 1999 and 2003, where we made two samples in the summer (January-February) and one in winter (July).

For rivers Pilmaiquén, Petrohué, and Negro Hornopirén, data on annual water discharge were obtained from official records (DGA, Dirección Nacional de Aguas, Gobierno de Chile). The flow speed, river bottom features, and morphometric parameters were measured directly with a Hydro-Bios Kiel (catalog number 445 500-033) flow meter (Germany).

At Lago Puyehue we used information on chinook "population" reported by Soto et al. (2001a), and Soto et al. (2006). Data from this lake were obtained from gillnetting near the lake shore between August 1999 and November 2001. Lago Puyehue, is one of many lakes of glacial origin, within the Araucanian Lakes district; it is considered oligotrophic to mesotrophic, temperate monomictic (Soto 2002). The only outlet of the lake is the Río Pilmaiquén with a small hydropower plant and waterfall of $17 \mathrm{~m}$ in height, less than $10 \mathrm{~km}$ from its origin; this river connects with the Río Bueno which in turn reaches the sea (Fig. 1). This lake had a Chinook cage aquaculture facility, one of the few sites in Chile where the species was cultured.

In total, by using gill nets and electrofishing we measured 122 adult individuals in Lago Puyehue, 68 adults in Petrohué during reproductive season and three individuals in Hornopirén. We were not able to find reproductive returns in Río Poicas. With electrofishing we identified and measured at least 20 juvenile individuals per species per sample on each sampling trip.

\section{Argentinean rivers}

The rivers sampled were Futaleufú, Carrenleufú and Pico, their geographic position and main watershed are shown in Table 1, all of them located east from the Andes range. Río Futaleufú belonging to a large trans-Andean basin (Table 1) originates in the southern zone of Los Alerces National Park in Argentina (Fig. 1), and crosses to Chile reaching the Pacific Ocean through the Lago Yelcho and river of the same name (Fig. 1).

The Río Carrenleufú basin drains towards the Pacific slope, taking the Rio Pico inflow, through the Río Corcovado, and after flowing $52.8 \mathrm{~km}$ it reaches the Pacific Ocean through the Río Palena in Chile (Fig. 1, Table 1). Maximum temperatures reported for the Futaleufú, Carrenleufú and Pico rivers were usually in January, being respectively 15.9, 15.8 , and $13.1{ }^{\circ} \mathrm{C}$, while annual reported averages are $11.4,11.3$, and $10.8{ }^{\circ} \mathrm{C}$ (Coronato \& Del Valle 1988).

The two spawning sites at Carreleufú river, Argentina, corresponded to areas of old riverbeds and deep pools, with arboreal and bushy vegetation on both banks. The substratum was made of spherical and semispherical gravel black to gray in color, interspersed with sandy areas and larger 
boulders and rocks. The average width of the river is approximately $80 \mathrm{~m}$, with a mean depth of $1.5 \mathrm{~m}$. In the Río Futaleufú (Argentina side), the observed spawning site was a branch of 200 to $300 \mathrm{~m}$ in length, with an average width of 20 $\mathrm{m}$, an approximate depth of $1.2 \mathrm{~m}$ and similar substrate to that described above, which was also the case in Río Pico. A common feature to riparian zones in all the rivers both in Chile and in Argentina, is the relatively pristine condition of the vegetation and land use in the catchments.

The collection of biological data from the Argentinean basins was carried out during the sport fishery seasons in 1999-2000 (October through March), and 2000-2001 (November through April). Fish samples were collected by sport fishing, in addition to the use of multifilament gillnets in Río Pico in March 2000 and in April 2001 in Río Futaleufú. Data from Río Carrenleufú was provided by fishermen and villagers only. In Argentina 35 adult individuals were measured, considering 19 in Río Corcovado, 10 in Río Futaleufú, and six in Río Pico.

All fish disregarding the capture method, were measured, weighed, and sexed. In Argentina it was not possible to do electro fishing for collection of juvenile specimens.

\section{RESULTS}

Assessment of reproductive conditions and spawning events

At Los Patos in Río Petrohué, massive spawning returns were observed in 1995, 1996, 2000, and then again in 2004 (Table 2). Also, there have been local reports of Chinook runs in this area before 1995, but the magnitude is unknown. The peak season for the Chinook spawning includes mid March through mid May (Fig. 2). Direct observations made at the site indicated pairs of chinook salmon near their redds or in holding groups of 5-12 individuals. Similar returns were observed in March 2004 and April 2005 at Río Hueñu Hueñu, another tributary to the Río Petrohué, which runs into it about $2 \mathrm{~km}$ below Los Patos. However, we have not systematically sampled Río Hueñu Hueñu.

Captured of Chinooks at Los Patos in Río Petrohué, since April 1995, ranged in size between 73 and $130 \mathrm{~cm}$ total length (Fig. 3), with a modal size at $95 \mathrm{~cm}$ and a weight distribution between 5 and $13.4 \mathrm{~kg}$. Using the information for the years with highest returns it is thus possible to estimate a biomass of approximately $200-600 \mathrm{~kg}$ along $100 \mathrm{~m}$ of river area (Table 2).

TABLE 2

Estimates (density/biomass on 100 m of lineal river shore) of spawning salmon at "Los Patos, Río Petrohué" between 1995 and 2004 and prevalent climatic conditions prior to the spawning

Estimaciones (densidad/biomasa a lo largo de $100 \mathrm{~m}$ de línea de costa) de salmones chinook desovantes en el sector Los Patos, Río Petrohué, entre 1995 y 2004 y condiciones climáticas prevalentes previas a la etapa reproductiva

\begin{tabular}{lccc}
\hline Year & $\begin{array}{c}\text { Accumulated precipitation } \\
(\text { Jan-April })(\mathrm{mm})\end{array}$ & $\begin{array}{c}\text { Average river discharge } \\
(\mathrm{Jan}-A p r i l)\left(\mathrm{m}^{3} \mathrm{seg}^{-1}\right)\end{array}$ & $\begin{array}{c}\text { Density/biomass } \\
(\mathrm{kg} \text { salmon in } 100 \mathrm{~m})\end{array}$ \\
\hline 1995 & 732 & 411.6 & $200-300$ \\
1996 & 785 & 406.1 & $450-500$ \\
1997 & 909 & 399.6 & $<10$ \\
1998 & 455 & 314.9 & $<10$ \\
1999 & 440 & 240.4 & 80 \\
2000 & 718 & 343.2 & None* \\
2001 & 688 & 677.1 & 10 \\
2002 & 780 & 446.8 & $<10$ \\
2003 & 581 & 501.7 & $500-600$ \\
2004 & 541 & 361.8 & 50
\end{tabular}

* No salmon spotted during sampling visits 


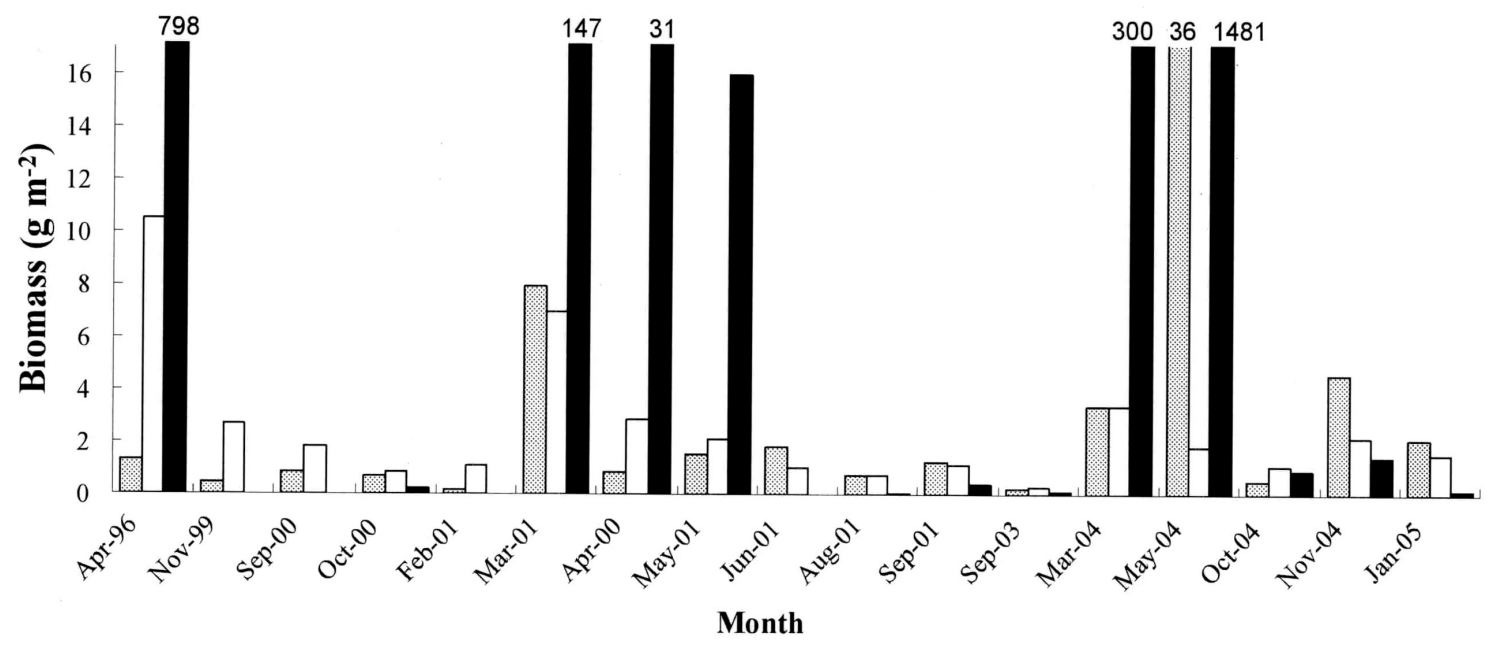

$\square$ O. mykiss

$\square$ S. trutta

口. tshawytsha

Fig. 2: Biomass per species in Petrohué-Los Patos site (all sampling methods combined). For $O$. tshawytscha, biomass over $10 \mathrm{~g} \mathrm{~m}^{-2}$ corresponds solely to spawners, the bars have been cut to facilitate graphical comparison but the total values are indicated above each.

Biomasa por especie en el Río Petrohué- sector Los Patos (todos los métodos de muestreo combinados). Aquellas biomasas de $O$. tshawytscha sobre $10 \mathrm{~g} \mathrm{~m}^{-2}$ corresponden solamente a desovantes, las barras han sido cortadas en su parte superior para facilitar la comparación gráfica pero los valores totales aparecen junto a cada una.

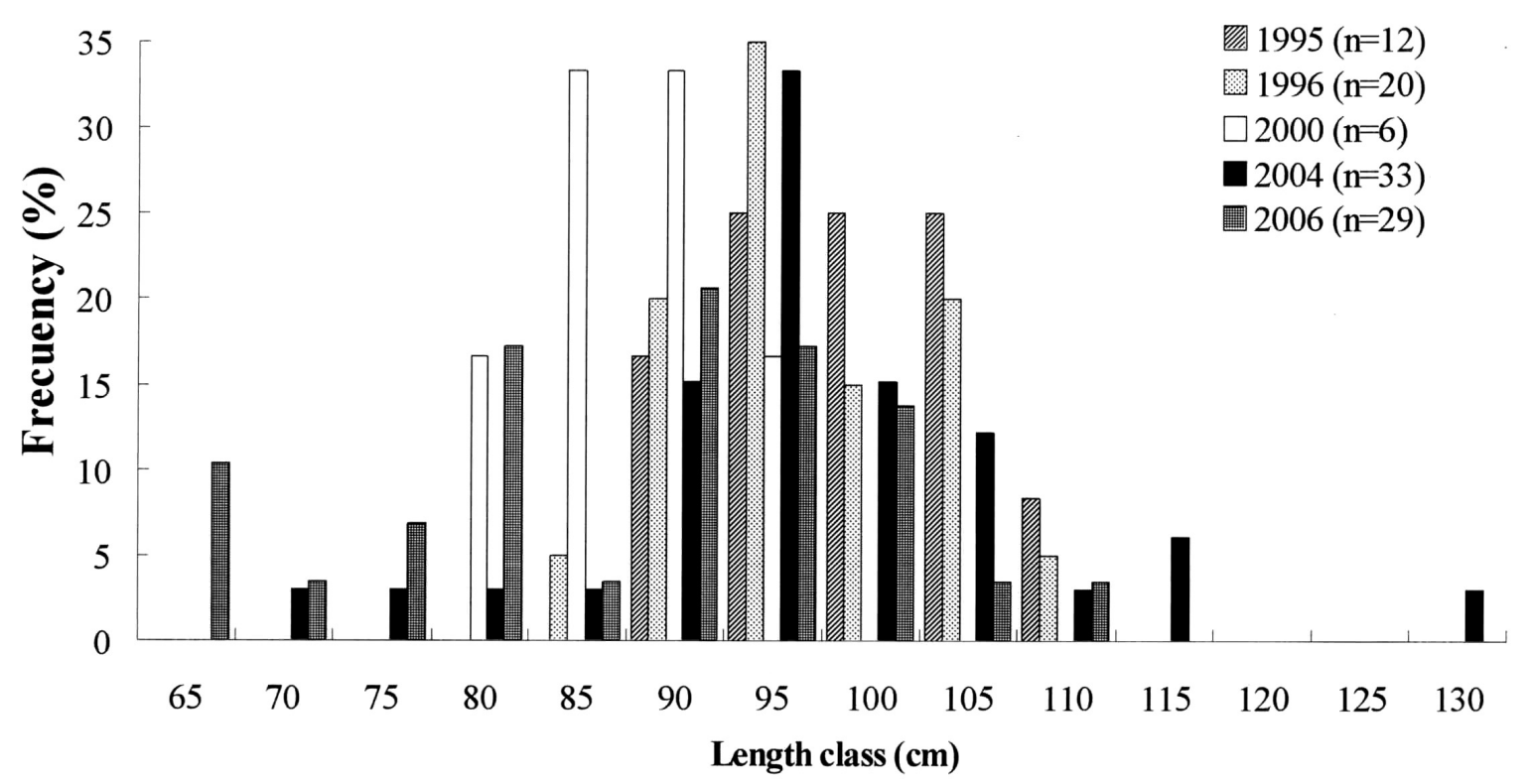

Fig. 3: Size classes of spawning chinook at Los Patos site, Río Petrohué (1995, 1996, 2000 and 2004).

Clases de talla de los chinook desovantes en el sector Los Patos, Río Petrohué (1995, 1996, 2000 y 2004). 
Based on the number of chinook redds counted in a subsection of the river, we estimated around 420 to 560 as the total number of redds in this secondary river channel used as spawning site. In 1996 an estimated total of 800 individuals reached this part of the river. The evaluation of gonads of un-spawned females, between 85 to $95 \mathrm{~cm}$ total lengths, ranged between 4,180 to 4,950 mature eggs. A fraction of the spawned eggs is eaten by other fish (brown and rainbow trout, coho salmon and brook trout, Salvelinus fontinalis) as was attested by the stomachs packed with eggs, and by freshwater crabs (Aegla sp.) which congregated to feed on the eggs among the cobbles at each redd.

The intensity of the returns has varied from year to year. Evaluations at the same site in 1999 and again in 2000 showed either so few individuals that were virtually impossible to sample (1999) or a much lesser return (2000) that did not exceed $80 \mathrm{~kg}$ along $100 \mathrm{~m}$ of the river (Table 2). In 2004, a massive spawning even larger than the one reported in 1996, took place (Table 2). This allowed for a more complete sampling from March to May 2004; in this case, returning Chinooks were rather larger than in previous years, total length ranged from 67 to $130 \mathrm{~cm}$ and the average was $94.9 \mathrm{~cm}$ (Fig. 3). Further, the largest fish biomass was recorded in the river during March, April and May, corresponding to spawning Chinook (between 60 and $130 \mathrm{~cm}$ total length) reaching more than $1000 \mathrm{~g} \mathrm{~m}^{-2}$ during spawning in May 2004. Over the same months, increases in the biomass of rainbow trout and brown trout were reported (Fig. 2).

Table 2 indicates Chinook estimated biomass density for every $100 \mathrm{~m}$ along the river in the area of Los Patos lagoon, over the past 10 years. Accumulated rainfall and average river discharge are also shown for the period January-April, the preceding and actual months of the spawning. Though the accumulated precipitation per se might not have a direct effect probably due to the regulating effect of Lago Todos Los Santos, average river discharge seems to affect the intensity of the returns. On the one hand, either too little a discharge would not allow for strong enough signals or sufficient water for the upward return, or on the other hand, too much a discharge would wash away fish from the spawning grounds. The fact is that the greatest return years took place when the average river discharge was between 362 to $412 \mathrm{~m}^{3} \mathrm{seg}^{-1}$ (Table 2).

At Lago Puyehue, the evaluation of population structure showed individuals ranging from 20 to $90 \mathrm{~cm}$ in total length, $90 \%$ of the individuals over $40 \mathrm{~cm}$ had mature gonads by the end of April both in 2000 and 2001 when population density increased by the lake shore (Soto et al. 2001a). However, there is no information on massive reproductive runs in tributaries to the lake and we have no samples (nor other reports) that include juvenile Chinook in the streams (Soto \& Arismendi 2005).

Specimens caught in basins of Argentinean origin were between 50 and $130 \mathrm{~cm}$ of total length; most of the individuals ranging from 80 to $100 \mathrm{~cm}$ (Fig. 4), unfortunately we could not obtain reliable information on the size of returns or about inter-annual variability.

Length-weight relationships varied for the different environments in Chile and Argentina. Lago Puyehue had adult individuals of the smallest sizes, while returns in Argentina showed slightly larger sizes than those in Chile, though average size were not statistically different (Mann-Whitney U-test, $\mathrm{P}=0.058$ ). In addition, for those Chinook with similar lengths in Chilean and Argentinean basins, the latter had larger weights (Fig. 4).

\section{Juvenile population features}

In the Río Petrohué a total of 16 samplings with electro fishing were made from 1999 to January 2005, covering all four seasons. Brown trout (Salmo trutta) was the prevailing species (Fig. 2), followed by rainbow trout (Oncorhynchus mykiss) and chinook (O. tshawytscha); all of them with abundance generally below 0.2 individuals $\mathrm{m}^{-2}$ (Fig. 5). Rainbow and brown trout were captured in all the samplings, and were within the range 0.2 to $36 \mathrm{~g} \mathrm{~m}^{-2}$ (Fig. 2). Juvenile Chinook captured by our method reached highest density between September and October especially in 2004 (Fig. 6 ) while they were mostly absent in the fall months, February to June (Fig. 6).

At rivers Poicas and Negro-Hornopirén average density of juveniles were 0.35 and 0.03 individuals $\mathrm{m}^{-2}$ respectively although variability 


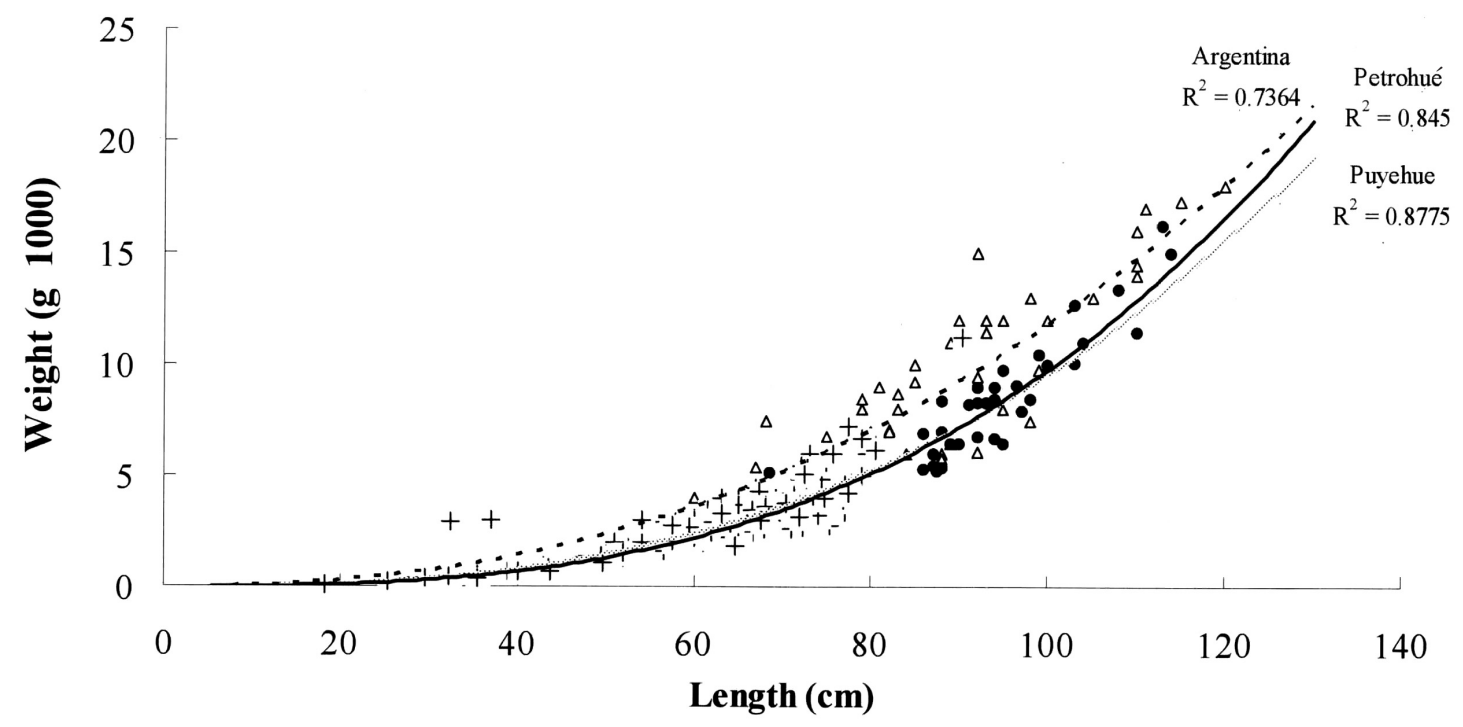

$\Delta$ Argentina

- Petrohué

+ Puyehue

Fig. 4: Total length versus total weight for Chinook salmon. All sites, (accumulated data - all fishing methods).

Longitud total versus peso total para el salmón chinook. Se incluyen todos los sitios (datos acumulados-todos los métodos de pesca).

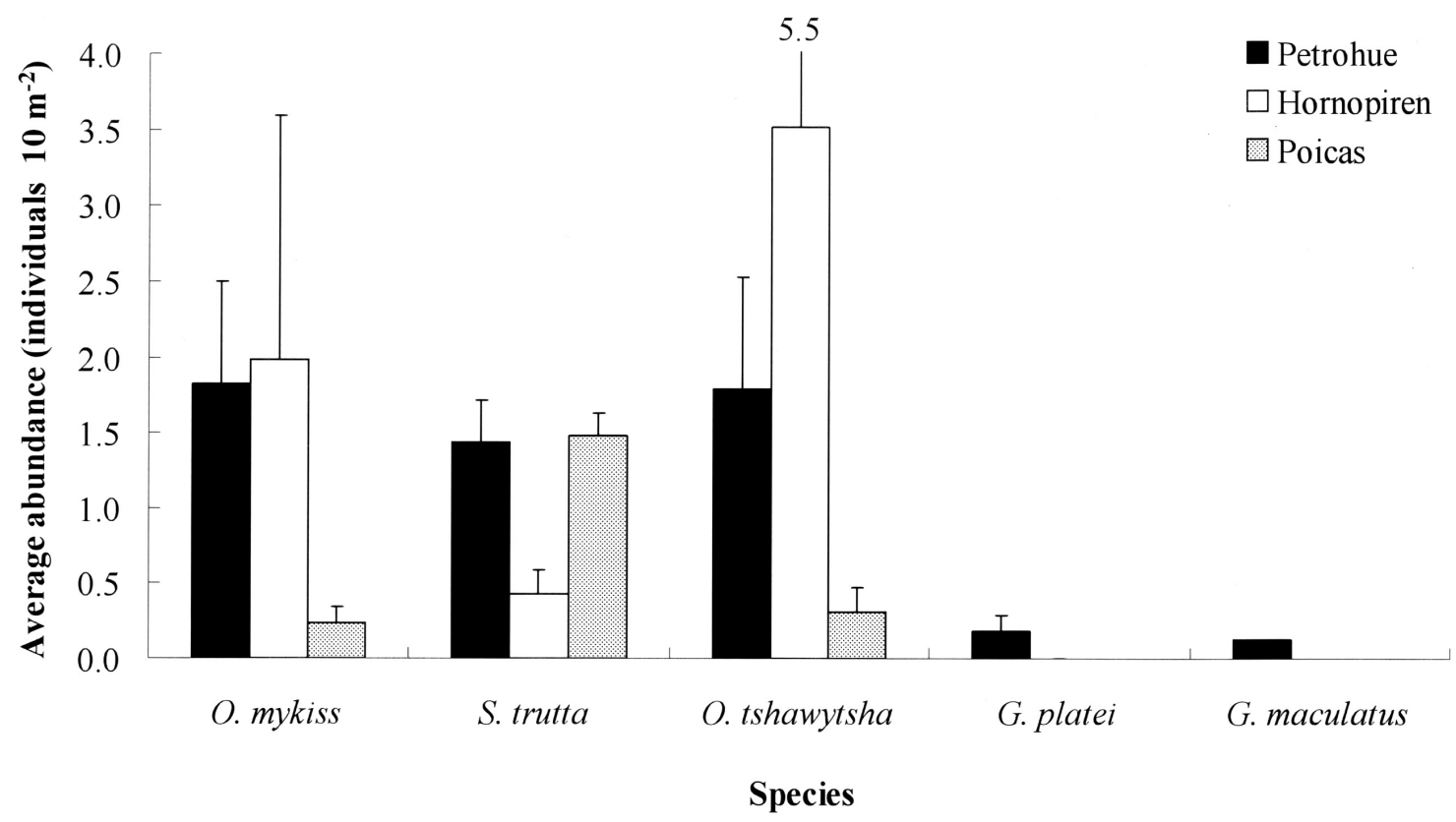

Fig. 5: Average abundance of each salmon-trout species in the sampled Chilean rivers (electrofishing). Error bars represent standard error. In the white column for Chinook (O. tshawytscha) the number (5.5) represent the top value with the error bar.

Abundancia promedio de cada especie de salmón-trucha en los ríos chilenos muestreados (pesca eléctrica). Las barras de error representan error estándar. En la columna blanca correspondiente a Chinook (O. tshawytscha) el número (5.5) representa el valor incluyendo la barra de error. 


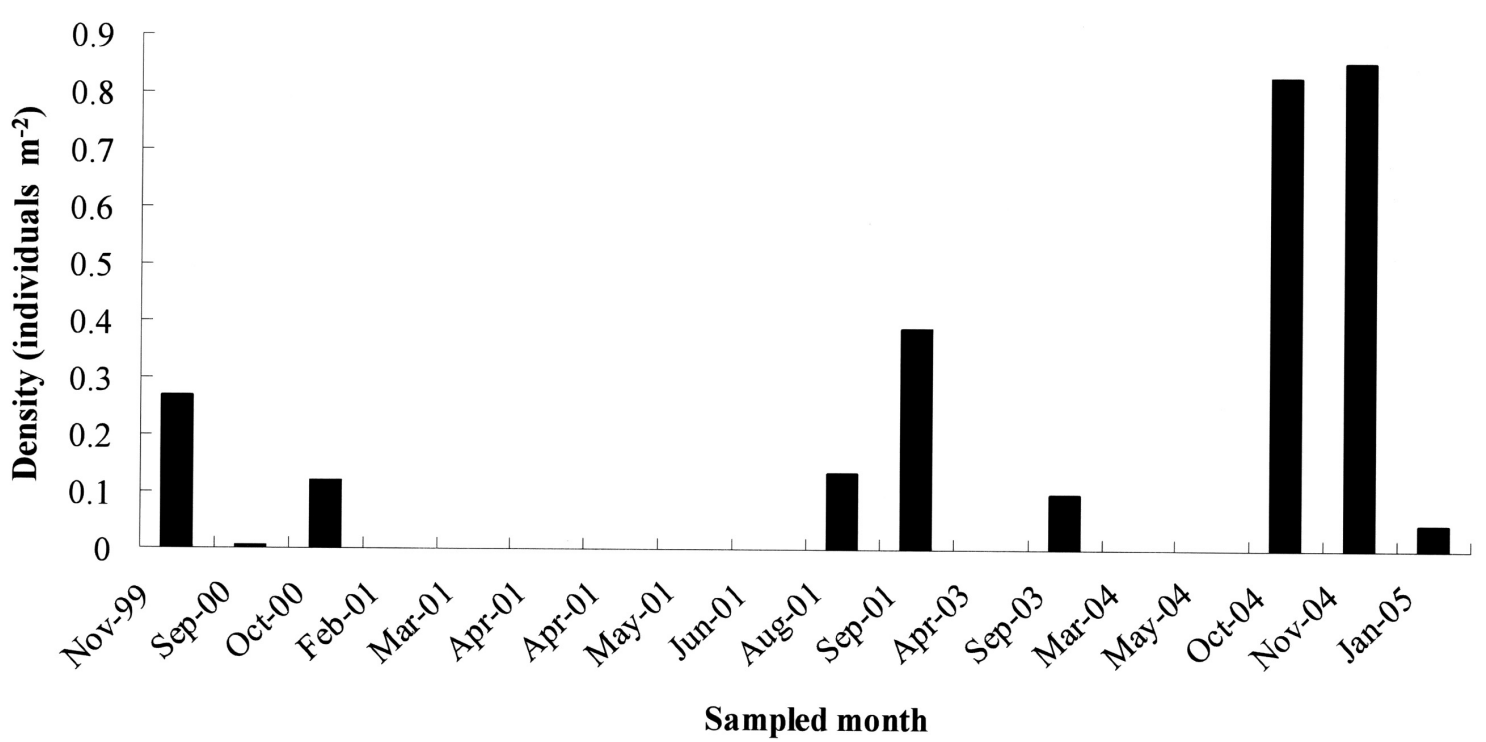

Fig. 6: Density of juvenile chinook at Los Patos-Río Petrohué. Only sampled months are shown.

Densidad de juveniles de chinook el sector los Patos-Río Petrohué. Solo se indican los meses muestreados.

among sampling dates was much higher in Río Negro-Hornopirén (Fig. 5). Here the largest density was observed in May (1.3 individuals $\mathrm{m}^{-2}$ ) when average total length of individuals was $12.3 \mathrm{~cm}$, while in August we observed the largest size (Fig. 7); in Río Poicas the largest individuals $(8-11 \mathrm{~cm})$ were observed in July (Fig. 7) and January (7.6-9.3 cm).

Dissolved inorganic nitrogen (DIN) concentrations measured on spawning grounds water were not much different from those in the same river above the latter, or from those measured on comparable Andean rivers of the region (Soto et al. 2006). Yet the highest values on the spawning area were observed at the time or right after maximum spawning (Fig. 8). On the other hand, dissolved inorganic phosphorus, values were much higher than those up river or on other comparable rivers. Concentrations also showed temporal fluctuations with the highest values on the peak spawning (Fig. 8).

\section{DISCUSSION}

Under the US Species Act (ESA), different populations of chinook salmon are at present cited as threatened or endangered. The decline of these populations along with the other Pacific salmon species have been caused by a mixture of factors including habitat destruction, over harvesting and hydropower dams (Lichatowich 1999, Willson 2003). Quite a different situation seems to be taking place in southern South America, where chinook salmon is conquering new environments.

Anadromous salmon play an important role in their natural environments particularly supplying marine derived nutrients to head waters. The decline of Pacific salmon in North America, including that of Chinook populations, is producing and impoverishment of the upper basins and there is a disruption of a normal ocean-land connection (Gresh et al. 2000, Naiman et al. 2002). The opposite situation is taking place in southern South America where apparently the accidental escapes of chinook salmon from aquaculture have produced increasingly important reproductive returns, "escapements", to upper basins in Chile and Argentina. This could be in turn, an ecosystemic disruption since no such connection existed within evolutionary scales in these southern ecosystems.

\section{Origin and success of the reproductive populations}

Attempts to introduce populations of anadromous species in different places in the world have mostly failed. The exception can be found in New Zealand where successful returns 


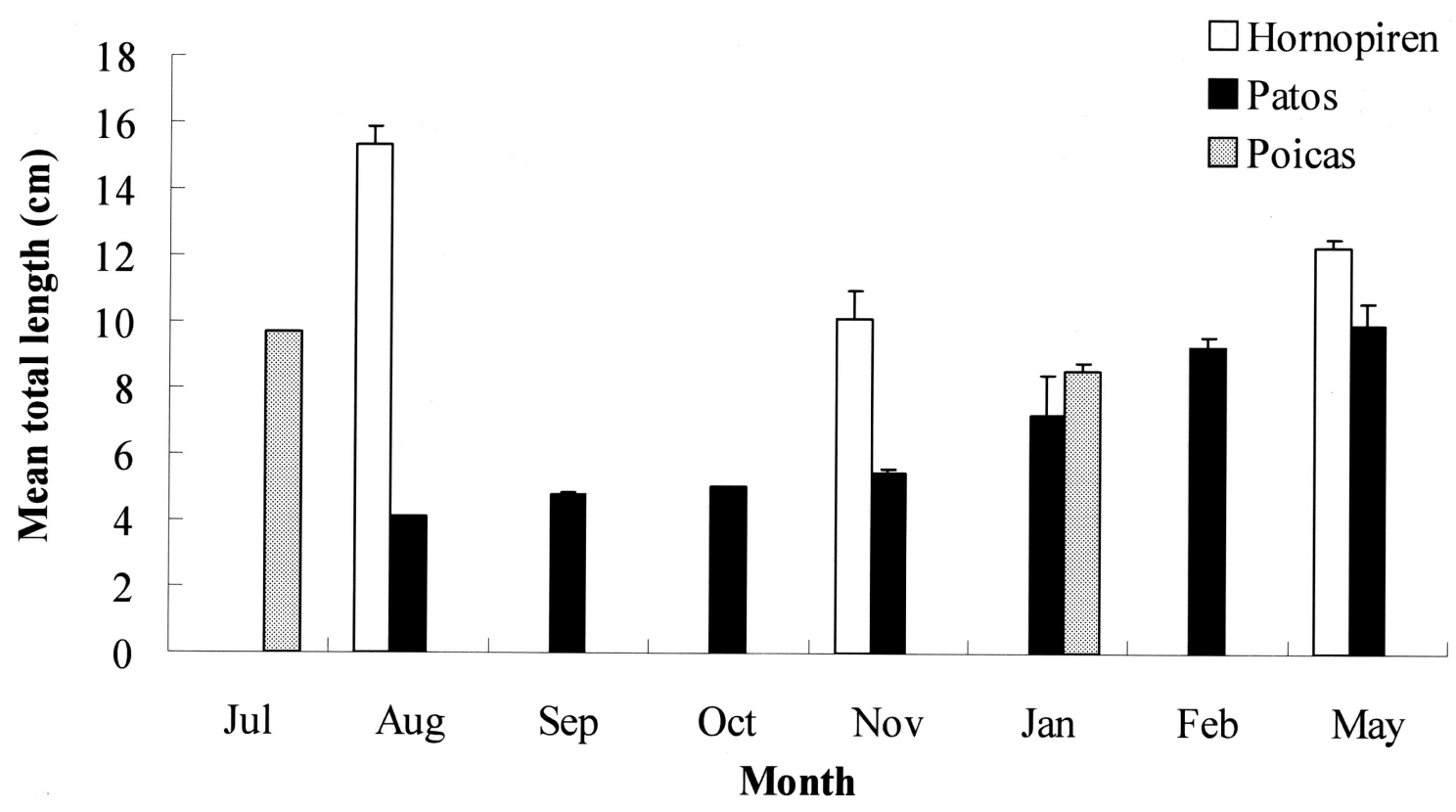

Fig. 7: Monthly average length of juvenile chinook at Los Patos, Río Petrohué.

Longitud promedio mensual de juveniles de chinook en el sector Los Patos, Río Petrohué.

of chinook (after seeding eggs and juveniles) were already observed between 1901 to 1907. Today there are numerous reproductive populations in that country (McDowall 1990).

However, in Chile early chinook introduction attempts (before 1970) with eggs were apparently not successful and persistent returns were not observed until the 1990s. These could have originated in the ranching attempt carried out in 1975 (Basulto 2003) but most likely they resulted from salmon farming accidental escapes since 1980 (Soto et al. 2001b). Accidentally farm escaped juvenile and adult salmon should have higher survival probabilities than eggs.

It is surprising that this species, which accounts for a very small proportion of the salmon farming (less than $2 \%$ ) and the smallest proportion of escapees, could be successful in establishing feral populations. Total salmon escaped from farming in the inner seas of southern Chile between 1994 and 1996 amounted to more than 3 million individuals, including coho salmon, rainbow trout, Atlantic salmon and chinook. The latter could have reached up to 50 thousand individuals corresponding to the $1+$ age class or older, and with an individual mass around $1 \mathrm{~kg}$ (Soto et al. 2001b). However, the first large reported reproductive run in Petrohué occurred in April 1995 (Table 2) and perhaps these individuals originated in previous escapes to those reported in 1994. The size distribution of the reproductive individuals (Fig. 3), according to the length-age relationship proposed by Healy (1991) for Alaskan chinook populations, should correspond to individuals of 6 to 8 years old.

There were only two sites in the inner seas of Chiloé (Fig. 1) where Chinook salmon were farmed, one in Hornopirén and other near Calbuco (Fig. 1), localities which could have originated straying populations moving slightly north to Reloncavi Estuary and Río Petrohué, eventually to Río Puelo and south to Futaleufú basin and to Chubut Province in Argentina. Accordingly, Grosman (1992) reported the first noticeable chinook runs near Esquel, Argentina (Fig. 1) by 1990, suggesting that reproductive returns became more frequent during that decade and reinforcing the hypothesis that they might have originated from farming escapees after 1980. Individuals reaching Argentina basins are slightly larger than those reproducing in Petrohué (Fig. 4). On the other hand the farm escaped individuals in Lago Puyehue, although can reach sexual maturity, they do not seem to be able to reach the ocean and there are no observations of successful 
reproductions in the affluent streams to the lake either (Soto \& Arismendi 2005). Probably the presence of the Pilmaiquén hydroelectric dam in the outlet of the lake is the main barrier to outgoing fish and for returning reproductive individuals. Nevertheless there are reports of reproductive returns to a tributary below the dam (Javier Marín, personal communication). The presence of hydropower and irrigation dams have been one of the most important damaging factors blamed to cause the decline of chinook populations in the Pacific coast of Oregon and British Columbia (Willson 2003).

The reproductive population in Petrohué seems to be the typical ocean type according to the characteristics mentioned by Haley (1991) and Brannon et al. (2004). These are individuals which run in late summer/early fall (late March- early May, Fig. 2), juveniles with short stream residence since their hatching probably takes place within three to four months after spawning (July-August) and youngsters are apparently gone to sea within the first year of age. We conclude this since we observed the last juvenile individual at Los Patos in February (at $10 \mathrm{~cm}$ of total length) but the largest proportion of the juvenile population was gone from the reproduction area after November (Fig. 6) when they had reached 5 to $7 \mathrm{~cm}$ of TL (Fig. 7). Since the river is rather short $(30 \mathrm{~km}$, Table 1$)$, these juveniles could reach the fjord marine waters within the 0 -age. Río Petrohué as the lake outlet has small temperature variation with the lowest of $8{ }^{\circ} \mathrm{C}$ in August increasing to $14^{\circ} \mathrm{C}$ in February (Campos et al. 1990). Such conditions offer comparatively high temperatures possibly
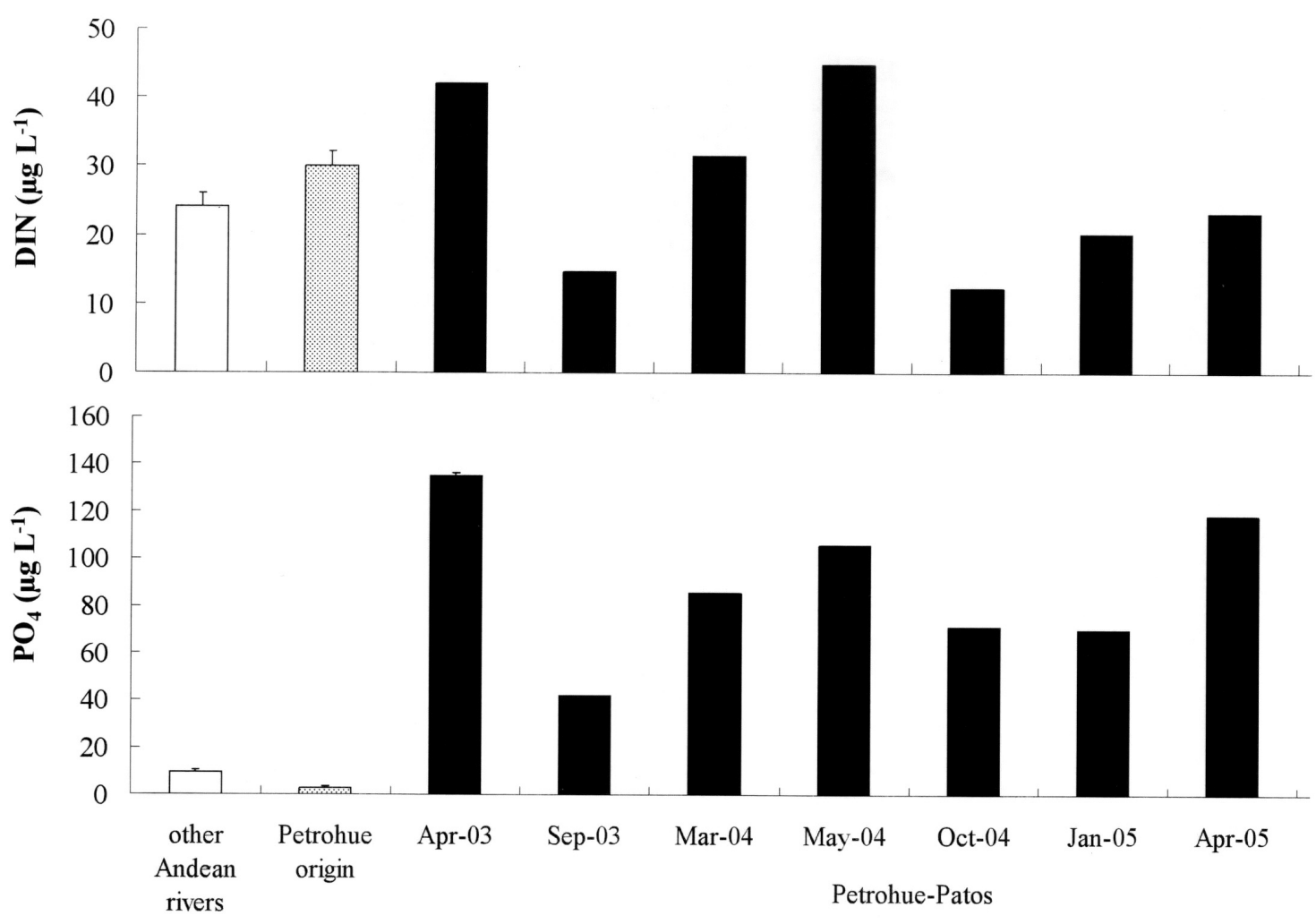

Site

Fig. 8: Above; concentration of dissolved inorganic nitrogen $\left(\mathrm{DIN}=\mathrm{NO}_{2}+\mathrm{NO}_{3}+\mathrm{NH}_{4}\right)$ in other similar Andean rivers and in Rio Petrohué above spawning grounds (SPW) and on the spawning site (black bars) on different sampling occasions. Error bars are standard errors for duplicate samples.

Arriba, concentración de nitrógeno inorgánico disuelto ( $\mathrm{DIN}=\mathrm{NO}_{2}+\mathrm{NO}_{3}+\mathrm{NH}_{4}$ ) en otros ríos Andinos similares y en el Río Petrohué más arriba del lugar de desove (SPW) y en el área de desove (barras negras) en diferentes momentos de muestreo. Las barras de error corresponden a error estándar para muestras duplicadas. 
shortening hatching time, facilitating fast growth and early ocean migration as suggested by Brannon et al. (2004). Most chinook rivers in North America, for example those in the Columbia basin, have much lower winter temperatures usually below $5{ }^{\circ} \mathrm{C}$. Although we have been able to check few females with complete gonads, fecundity seems lower (around 4500 eggs) than expected for ocean type (Healey 1991), yet this could be a sampling bias.

It is likely that chinook ocean type is very common at more southern latitudes, because rivers with present reproductive populations are also connected to head water lakes as in Petrohué, such is the case of Futaleufú basin and Carrenleufú basins. Most lakes in southern Chile and Argentina are monomictic, and lowest circulation temperatures in winter rarely fall below $8{ }^{\circ} \mathrm{C}$ and for a very short period (Soto 2002). Thus average rearing temperatures should be over $9^{\circ} \mathrm{C}$.

However, rivers born directly from wet precipitation and or from snow usually have lower temperatures as is the case in rivers Poicas and Negro-Hornopirén where winter temperatures can fall below $5{ }^{\circ} \mathrm{C}$. There it could be possible to find stream type chinook as seems to be the case at Poicas where we found the largest size individuals in July (Fig. 7).

Yet another factor, which we were not able to consider here, is the distance young fish have to go through to reach the ocean. This is the shortest in Petrohué and Negro rivers while is much longer for the trans-Andean basins which may force the juvenile fish to remain in the stream condition until they reach 1+ years of age. Indeed, according to Brannon et al. (2004) it could be possible to find a mixture of ocean type and stream type chinook populations.

\section{Why are Chinook so successful?}

It is intriguing that Chinook could be so successful, since it is the less cultured species while the more common cultured species (coho and Atlantic salmon) which have also escaped in greater numbers have not been that successful (Soto et al. 2001b).

Possible the most general and comprehensive explanation relates to the much greater plasticity and the diversity of life history modes of this species as compared with other salmonids (Healey 1991, Brennan et al. 2004). The possibility of going earlier or later to the marine environment, the variation in maturity, variation in the time to return to the natal stream are all characteristics which would make this species more successful because the possibility to adapt to different situations.

Another important reason is that these salmon apparently do not remain in the inner seas but could go to the open Pacific Ocean, thus escaping from artisanal fishing pressure in the inner seas. The latter has been the main factor controlling the spread of other salmon species escaped from aquaculture (Soto et al. 2001b).

Additional evidence pointing to salmon farming as the main recent source of Chinook is based on the increasing number of runs reported after 1990 (Fig. 1). Besides those shown here, there are numerous recent reports by fishermen catching chinook in a much wider latitudinal range from the Río Tolten watershed from the north $\left(39^{\circ} 05^{\prime} \mathrm{S}, 72^{\circ} 30^{\prime} \mathrm{W}\right)$ to Río Pascua in the south $\left(48^{\circ} 15^{\prime} \mathrm{S}, 73^{\circ} 03^{\prime} \mathrm{W}\right)$. The rivers Vargas and Jaramillo $\left(47^{\circ} 41^{\prime} \mathrm{S}, 73^{\circ} 00^{\prime}\right.$ W) are apparently becoming popular among fisherman due to the large size of Chinook $(\mathrm{N}$. Sanchez personal communication). On the other hand, Ciancio et al. (2005) have been reporting chinooks in the Río Santa Cruz in the Atlantic basin in Argentina which the authors suggest as originating in a ranching activity near Puerto Natales in southern Chile $\left(51^{\circ} 40^{\prime}\right.$ $\left.\mathrm{S}, 73^{\circ} 32^{\prime} \mathrm{W}\right)$. Thus, it is evident that this salmon species is establishing numerous reproductive populations and the migrating individuals could develop large marine populations as well. The pristine environmental conditions of rivers in southern Chile and Argentina seem indeed ideal for the species.

Unfortunately we still have limited data in order to propose explanations for inter annual spawning variability of returns even at Los Patos site in Petrohué (Table 2). There is some evidence that long term climatic trends or regime shifts affect Chinook populations in North America (Tolimeri \& Levin 2004). Thus, it is likely that El Niño Southern Oscillation may have some effect on Chinook salmon establishment in southern Chile and Argentina, particularly because this species could go to the open ocean and its growth may be affected by variation in the upwelling which sustains productivity in the central-southern Chile coast. 
Potential ecosystem disruptions: nutrient enrichment

Along one $\mathrm{km}$ of river at the Los Patos site in Petrohué, the input of biomass during a given reproductive run can reach about 2,000 to 6,000 $\mathrm{kg}$ wet weight (Table 2). According to Larkin and Slaney (1997) estimates of marine derived nutrients (MDN) from salmon carcasses, a run of Chinook salmon such as that observed in 2004 could contribute about $8 \mathrm{~kg}$ of $\mathrm{N}$ and 0.3 $\mathrm{kg}$ of $\mathrm{P}$ on $100 \mathrm{~m}$ of river bed. Considering the Los Patos spawning area of approximately $15,000 \mathrm{~m}^{2}$, the supply of $\mathrm{N}$ and $\mathrm{P}$ could amount to $4.8 \mathrm{~g}^{2}$ of $\mathrm{N} \mathrm{m}^{-2}$ and 0.4 of $\mathrm{P} \mathrm{m}^{-2}$. These estimated values are comparable to some historical nutrient supplies such as those reported by Suzumoto (1992) in a $100 \mathrm{~m}$ stretch of Willapa River in the coast of Washington (Table 3). However according to this author, the present values at that site are much lower due to the decline of salmon populations.

\section{TABLE 3}

Comparative fish biomass and potential loads of $\mathrm{N}$ and $\mathrm{P}$ ( $\mathrm{kg}$ in $100 \mathrm{~m}$ of river length) for a North American typical river in pre industrial and present times (Willapa Bay Drainage basin, redrawn from Suzumoto 1992) and at Los Patos area in Río Petrohué

Comparación de la biomasa de peces y aportes estimados de $\mathrm{N}$ y $\mathrm{P}$ ( $\mathrm{kg}$ en $100 \mathrm{~m}$ de río) en un típico río norteamericano, en una época preindustrial y actual (Cuenca de la Bahía del Río Willapa, adaptado de Suzumoto 1992) y en el sector Los Patos del Río Petrohué

\begin{tabular}{lccc}
\hline Variable & $\begin{array}{c}\text { Willapa } \\
\text { Historical }\end{array}$ & $\begin{array}{c}\text { Willapa } \\
\text { Present }\end{array}$ & Los Patos* \\
\hline Biomass & $82-140$ & 8.6 & 144 \\
Nitrogen & $8-14$ & 0.9 & 13.8 \\
Phosphorus & $0.3-0.5$ & 0.03 & 0.57 \\
\hline
\end{tabular}

*Average 1995-2004

We have not been able yet to demonstrate the effect of these MDN in food webs from southern South America, while such effects have been widely explored for the Pacific coast of North America (Naiman et al. 2002). However our measurements of dissolved inorganic nutrients at the site show a strong effect particularly on dissolved phosphorus
(Fig. 8). Since there is a short distance (less than $5 \mathrm{~km}$ ) from the origin of Río Petrohué at the outlet of Lago Todos Los Santos and the spawning site at Los Patos, with no other potential nutrient sources in between, it is reasonable to blame salmon carcasses for the $\mathrm{PO}_{4}$ and DIN increases. This is more striking for $\mathrm{PO}_{4}$ since values are usually very low in most Andean streams and rivers including Río Petrohué at its origin (Fig. 8).

Because there is no natural removal of carcasses in our streams, such as bears do in the Chinook native environments (Naiman et al. 2002), it is likely that the impact of MDN would be more concentrated in immediate surroundings of streams and rivers. Although there is some consumption of carcasses by large scavenger birds such as the "tiuque" Milvago chimango, and the "caracara" Polyborus plancus whom could play de role in spreading nutrients to other parts of the basins.

\section{Effects on aquatic biodiversity}

There is no evidence for a negative effect on trout population as it has been suggested by sport fishermen, on the contrary trout biomass of both species seem to increase with chinook spawning events (Fig. 2). This is not surprising since Chinook are subsidizing the river with additional food including eggs and carcasses. McDowall (1990) describes similar effects after introduced chinook spawning in New Zealand, when trout populations were eventually benefited by Chinook. Soto et al. (2006) have shown that rainbow trout and brown trout are the most common fish in most rivers of Southern Chile while native fish species are rare and often absent from Andean streams and rivers such those reported here (Fig. 5). Therefore the most likely chinook interactions will be with both trout species.

The impact of growing adults at sea remains to be evaluated, yet their feeding behavior and predacious nature as described in North America (Healey 1991) implies a potential effect on some marine resources particularly pelagic organisms. Since the Chilean Ocean coast is very productive it is likely that Chinook populations will grow well as they are likely to be successful as well in some areas of the Patagonia Atlantic as proposed by Ciancio et al. (2005) therefore establishing populations 
suitable for a fishery in both Atlantic and Pacific seas could be a mater of time.

\section{Legal and social implications of Chinook establishment}

The establishment of chinook populations in southern South America could generate at least two social problems; first they could damage present fishery resources both for artisanal and industrial fisheries or at least they could pose a threat with social implications. Another potential impact is the possibility that Chinook salmon may develop into a commercial fishery itself. Such possibility has been strongly denied and opposed in the past by salmon farmers and so far salmon fishery or marketing of salmonids other than farmed has not been authorized in Chile (Soto et al. 2001b).

Sport fishing is another flourishing endeavor in southern Chile but much better established in Argentina. The presence of large Chinook during the fishing season causes mixed opinions and problems. On the one hand Chinook reproduction in southern Chile and Argentina according to our data occurs between March and early May, coinciding with the peak of the sport fishing season. Thus, the reproductive Chinook are not protected while rainbow trout and brown trout are protected by the non-fishing season from middle May until October. Different groups of anglers and fly fishing associations have various opinions; some of them want the large Chinook for the early fishing season in the estuaries when they start going up the rivers. Others blame The Chinook runs for the decrease in the trout catch in late summer and fall; therefore, this is a polemic issue. Nevertheless, administrators should make decisions, at a governmental level, as to whether Chinook salmon should be allowed to settle or if measures should be adopted to prevent successful establishment. Rivers from southern South America, particularly in Chile and Argentina, could provide so far pristine environments similar to those Pacific salmon used to enjoy in North America before the onset of the "industrial economy" as explained by Lichatowich (1999). Thus, opportunities for the conservation of chinook global biodiversity may accrue from allowing the species to settle in southern South America. This conservation could take the form of populations, genes or even some "evolutionary significant units" ESUs (Levin \& Schiewe 2001) which are being lost in the northern hemisphere. But do we want these? We may need to know first if the potential losses to native biodiversity due to the presence of Chinook may compensate or justify allowing the establishment of this newcomer.

\section{CONCLUSIONS}

Chinook salmon populations are becoming established in several catchments of the Pacific coast of southern South America, including those draining directly from Chile and some draining from Argentina basins. Origin of these populations could be traced back to earlier ranching in Chiloé Island but more likely to escaped salmon from farms. Pristine conditions in main river basins seem to favor the settlement, while such condition is increasingly lost in the native habitats of the species in North America where its survival and distribution is threaten.

The establishment of the species posses important challenges to decision makers; Impact of this exotic species goes from the supply of marine derived nutrients to head waters, to the potential community disruption due to predation and competition both in freshwaters and marine systems, although the impact should be greater in the latter.

The establishment of Chinook is creating social conflicts and may have strong ecological effects especially on marine systems. Therefore there is the need of developing management tools and approaches to control the populations avoiding further ecosystem disruptions.

\section{ACKNOWLEDGEMENTS}

This research was funded by the FONDECYT grant 1020183, also by the FNDR (Fondo Nacional de Desarrollo Regional X Región, Chile), the Chilean Fisheries research fund (FIP) and the Forecos Nucleus (Millennium Scientific Initiative, Chile). We thank all the fishermen whom contributed with information. We are also very grateful to B. Penaluna and P. Araya for insightful comments and English proof to the manuscript. 


\section{LITERATURE CITED}

BASULTO S (2003) El largo viaje de los salmones: una crónica olvidada, Propagación y cultivo de especies acuáticas en Chile. Maval Limitada Editores, Santiago, Chile. 102 pp.

BRANNON EL, MS POWELL, TP QUINN \& A TALBOT (2004) Population structure of Columbia river basin chinook salmon and steelhead trout. Reviews in Fisheries Science 12: 99-232.

BRENNAN JS, KF HIGGINS, JR CORDELL \& VA STAMATIOU (2004) Juvenile salmon composition, timing distribution, and diet in marine nearshore waters of central Puget Sound in 2001-2002. King County Department of Natural Resources and Parks, Seattle, Washington, USA. 164 pp.

CAMPOS H (1974) Population studies of Galaxias maculatus (Jenyns) (Osteichthyes: Galaxiidae) in Chile with reference to the number of vertebrae. Studies on Neotropical Fauna and Environment 9: 55-76.

CAMPOS H, W STEFFEN, G AGUERO, O PARRA \& L ZUÑIGA (1990) Limnological study of lake Todos Los Santos (Chile): morphometry, physics, chemistry, plankton, and primary productivity. Archiv für Hydrobiologie 117: 453-484.

CAMPOS H, G DAZAROLA, B DYER, L FUENTES, J GAVILÁN, L HUAQUIN, G MARTÍNEZ, R MENÉNDEZ, G PEQUEÑO, F PONCE, V RUIZ, W SIELFELD, D SOTO, R VEGA \& I VILA (1998) Categorías de conservación de peces nativos de aguas continentales de Chile. Boletín del Museo Nacional de Historia Natural (Chile) 47: 101-222.

CIANCIO JE, MA PASCUAL, J LANCELOTTI, C ROSSI \& F BOTTO (2005) Natural colonization and establishment of a chinook salmon Oncorhynchus tshawytscha, population in the Santa Cruz River, an Atlantic basin of Patagonia. Environmental Biology of Fishes 74: 219-227.

CORONATO F \& H DEL VALLE (1988) Caracterización hídrica de las cuencas hidrográficas de la Provincia del Chubut. Centro Nacional Patagónico (CENPAT), Puerto Madrin, Argentina. 183 pp.

GEIST D \& D DAUBLE (1998) Redd site selection and spawning habitat use by fall chinook salmon: the importance of geomorphic features in large rivers. Environmental Management 22: 655-669.

GRESH T, J LICHATOWICH \& P SCHOONMAKER (2000) An estimation of historic and current levels of salmon production in the northeast Pacific ecosystem: evidence of a nutrient deficit in the freshwater systems of the Pacific northwest. Fisheries 25: 15-21.

GROSMAN F (1991) Presencia de "salmón rey", Oncorhynchus tshawytscha Walbaum, en las cuencas de los ríos Grande y Corcovado, Prov. del Chubut. Propuesta de pautas de manejo del recurso. Biología Acuática (Argentina) 15: 200-201.

GROSMAN F (1992) Algunos aspectos de la biología del salmón del Pacífico (Oncorhynchus tshawytscha) presente en la Provincia de Chubut. Informe Técnico 88, Centro de Ecología Aplicada del Neuquén y Japan International Cooperation Agency, Argentina. 12 pp.

HEALEY MC (1991) Life History of Chinook Salmon Oncorhynchus tshawytscha. In: Groot C \& L Margolis (ed) Pacific salmon life histories: 113393. University of British Columbia Press, Vancouver, British Columbia, Canada.
KLINE TC, JJ GOERING, OA MATHISEN, PH POE \& RS SCALAN (1993) Recycling of elements transported upstream by runs of Pacific salmon: II ${ }^{15} \mathrm{~N}$ and ${ }^{13} \mathrm{C}$ evidence in Kvichak river watershed, southwestern Alaska. Canadian Journal of Fisheries and Aquatic Sciences 50: 2350-2365.

LARKIN GA \& PA SLANEY (1997) Implications of trends in marine-derived nutrient influx to south coastal British Columbia salmonid production. Fisheries 22: 16-24.

LEVIN PS \& MH SCHIEWE (2001) Preserving salmon biodiversity. American Scientist 89: 220-227.

LICHATOWICH J (ed) (1999) Salmon without rivers. Island Press, Washington, District of Columbia, USA. 317 pp.

MCDOWALL RM (1990) New Zealand freshwater fishes; a natural history and guide. Heinemann Reed Maf Publishing Group, Auckland-Wellington, New Zealand. 553 pp.

MÉNDEZ R \& C MUNITA (1989) La salmonicultura en Chile. Fundación Chile, Santiago, Chile. 228 pp.

NAIMAN RJ, RE BILBY, DE SCHINDLER \& JM HEDFIELD (2002) Pacific salmon, nutrients and the dynamics of freshwater and riparian ecosystems. Ecosystems 5: 399-417.

NIEMEYER H \& P CERECEDA (1984) Hidrografía. Colección Geográfica de Chile. Tomo VIII. Instituto Geográfico Militar, Santiago, Chile. 308 pp.

PASCUAL MA, P MACCHI, J URBANSKY, F MARCOS, C RIVA-ROSSI, $M$ NOVARA \& $P$ DELL'ARCIPRETE (2002) Evaluating potential effects of exotic freshwater fish from incomplete species presence-absence data. Biological Invasions 4: 101-113.

RINGUELET RA, RH ARÁMBURU \& A ALONSO (1967) Los peces argentinos de agua dulce. Comisión de Investigaciones Científicas de la Provincia de Buenos Aires, Buenos Aires, Argentina. 602 pp.

SOTO D (2002) Oligotrophic patterns in southern Chile lakes: the relevance of nutrients and mixing depth. Revista Chilena de Historia Natural 75: 377-393.

SOTO D \& I ARISMENDI (2005) Fauna íctica de la cuenca del río Bueno: relevancia de los afluentes en la conservación de especies nativas. In: SmithRamírez C, J Armesto \& C Valdovinos (eds) Ecología y biodiversidad de los bosques de la Cordillera de la Costa de Chile: 418-426. Editorial Universitaria, Santiago, Chile.

SOTO D, I ARISMENDI, J SANZANA \& V BARRERA (2001a) Evaluación, ordenamiento y manejo del potencial biológico para la pesca deportiva de la Región de Los Lagos. Informe Proyecto FNDR Región de Los Lagos, Chile. 320 pp.

SOTO D, F JARA \& CA MORENO (2001b) Escaped salmon in the Chiloe and Aysén inner seas, southern Chile: facing ecological and social conflicts. Ecological Applications 11: 1750-1762.

SOTO D, I ARISMENDI, J GONZÁLEZ, E GUZMÁN, J SANZANA, F JARA, C JARA \& A LARA (2006) Southern Chile, trout and salmon country: conditions for invasion success and challenges for biodiversity conservation. Revista Chilena de Historia Natural 79: 97-117.

SUZUMOTO BK (1992) Willapa fisheries enhancement project. Report prepared for Willapa Alliance by Ecotrust, Portland, Oregon, USA. 73 pp.

TOLIMIERI N \& PS LEVIN (2004) Differences in responses of chinook salmon to climate $\mathrm{s} \mathrm{h}$ if t s : 
implications for conservation. Environmental Biology of Fishes 70:155-167.

WAUGH GD (1980) Salmon in New Zealand. In: Thorpe JE (ed) Salmon ranching: 277-303. Academic Press, London, United Kingdom.

WETZEL RG \& GE LIKENS (2000) Limnological

Associate Editor: Humberto González

Received April 7, 2003; accepted January 16, 2004 analyses. Third edition. Springer-Verlag, New York, New York, USA. 429 pp.

WILLSON PH (2003) Using population projection matrices to evaluate recovery strategies for Snake river spring and summer Chinook salmon. Conservation Biology 17: 782-794. 